\title{
Kapitalizmin Merkez Ülkelerinde Verimlilik, Sendikalaşma Yoğunluğu ve Ücretli Emek İlişkisi: Neoliberalizm Çerçevesinde Yapısal Kırılmalı Bir Analiz
}

\section{Ali ÇELIK ${ }^{1}$}

\section{The Relationship Between Productivity, Trade Union Density and Wage Labour in the}

Central Countries of Capitalism: A Structural Break Analysis in the Framework of

\section{Neoliberalism}

\begin{tabular}{l} 
ARTICLE INFO \\
\hline Article History: \\
Date Submitted: 17.10 .2019 \\
Date Accepted: 03.01.2020 \\
\hline JEL Classification: \\
B5, \\
C8, \\
J5.
\end{tabular}

Keywords:

Productivity,

Trade Union Density,

Wage Labor,

Neoliberalism

\begin{abstract}
Neoliberalism, is regarded as a combination of a series policies and strategies that put forward to overcome the structural crisis of 1973-74. The fact that capital developed new economic policies and production strategies to compensate for the declining profitability crisis of the 1970s is a result of its own condition of existence. The purpose of this study; to determine the extent to which the exit policies/strategies implemented under the name of neoliberalism affect working relations and living conditions of the working class. For this purpose; the effects of productivity and trade union density on labor income are investigated by using the data of 1970-2012 period for G-7 countries (Canada, Germany, Japan, Italy, France, England, USA) which are considered as the central countries of capitalism. In the empirical analysis; the unit root and cointegration tests which take into account the horizontal cross-sectional dependence were used. As a result of unit root test; the series becomes stable by taking the first differences. In the cointegration analysis considering structural breaks; the existence of the cointegration relationship between the series was accepted and the dates of structural breakage were consistent with the prior expectations. Finally, cointegration coefficients were estimated by CCE and CCMGE methods; ss a result of the analysis, it was seen that the increase in labor productivity had a negative effect on labor income. In the analysis which gives reliable results for the country units, this result is; It is statistically significant and interpretable for Italy, Japan and the United Kingdom. Throughout the panel, a linear relationship was found between trade union density and labor income. In other words, while the increases in the trade union density increase labor income; decreases in trade union density reduce labor income. However, this result is not statistically significant. In conclusion, this study presents empirical evidence on why capital wants to transform the working and living conditions of the working class as an exit strategy from the crisis.
\end{abstract}

\footnotetext{
${ }^{1}$ Dr. Öğr. Üyesi, İstanbul Gelişim Üniversitesi, Uygulamalı Bilimler Yüksekokulu, Uluslararası Ticaret Bölümü, alcelik@gelisim.edu.tr
} 


\section{Özet}

Neoliberalizm, 1973-74 yapısal krizinin bertaraf edilmesi amaciyla ortaya konulan bir dizi politika ve stratejinin birlikteliği olarak kabul edilmektedir. Sermayenin, 1970'li yıllardaki azalan karlılık krizini telafi etmek amacıyla yeni ekonomi politikaları ve üretim stratejileri geliştirmesi, kendi varlık koşulunun bir sonucudur. Çalışmanın amacı; neoliberalizm adı altında uygulanmaya konan krizden çıkış politikaları/stratejilerinin işçi sınıfının çalışma ilişkilerini ve yaşam koşullarını ne düzeyde etkilediğini tespit etmektir. Bu amaç çerçevesinde; verimlilik ile sendikalaşma yoğunluğunun emek gelirleri üzerindeki etkileri, kapitalizmin merkez ülkeleri olarak kabul edilen G-7 ülkeleri (Kanada, Almanya, Japonya, İtalya, Fransa, İngiltere, ABD) için 1970-2012 dönemi verileri kullanılarak araştırılmaktadır. Ampirik analizde; yatay kesit bağımlılığını göz önünde bulunduran birim kök ve eşbütünleşme testleri kullanılmıştır. Birim kök testi sonucunda; seriler, birinci farkları alınarak durağanlaşmaktadır. Yapısal kırılmaları dikkate alan eş bütünleşme testi sonucunda ise; seriler arasında eşbütünleşme ilişkisinin varlığ kabul edilmiş ve yapısal kırılma tarihleri önsel beklentilerle uyumlu sonuçlanmıştır. Son olarak, eş bütünleşme katsayıları CCE ve CCMGE yöntemleriyle tahmin edilmiştir; elde edilen bulgulara göre, emek verimliliğindeki artışın emek gelirlerini negatif yönde etkilediği saptanmıştır. Ülke birimleri için güvenilirliği tanıtlanan bu sonuç; İtalya, Japonya ve İngiltere için istatistiksel olarak anlamlı ve yorumlanabilir formdadır. Panelin genelinde ise sendikalaşma yoğunluğu ile emek gelirleri arasında doğrusal bir ilişki tespit edilmiştir. Daha açık bir ifadeyle; sendikalaşma yoğunluğundaki artışlar, emek gelirlerini yükseltirken; sendikalaşma yoğunluğundaki düşüşler emek gelirlerini azaltmaktadır. Ancak bu sonuç istatistiksel olarak anlamlı değildir. Sonuç olarak, çalışmada sermayenin krizden çıkış stratejisi olarak işçi sınıfının çalışma ve yaşam koşullarını neden dönüştürmek istediğinin ampirik kanitları ortaya konulmaktadır.

Anahtar Kelimeler: Verimlilik, Sendikalaşma Yoğunluğu, Ücretli Emek, Neoliberalizm

Jel Kodları: B5, C8, J5 


\section{GİRIŞ}

“Kapitalizmin tarihi, esas itibariyle krizlerin tarihidir'ş̧eklinde bir tanımlama yapılırsa şüphesiz önemli bir çoğunluk itiraz etmeyecektir². Kapitalizm, doğası gereği kriz üreten ve yeniden üreten bir üretim biçimidir. Kriz, kapitalist üretim biçimine içkindir. Harvey (2014) kapitalizm koşulları altında kriz olgusunu, canlı bir organizmada kan dolaşımının oynadığı hayati role benzetir. Böylece, kapitalist tarzda üretimin ya da başka bir ifadeyle sermayenin yeniden üretim sürecinin başlangıç anı, aynı zamanda kriz olgusunun tetikleyici öğelerinin de hareket geçmeye başladığı an olduğu ifade edilmelidir.

Sermayelerin belirli aralıklarla, iradelerinden bağımsız olarak maruz kaldıkları krizler temel olarak iki kategoriye ayrılır. Bunlar; 3-5 ve 7-10 yıllık periyotlarda ortaya çıkan sırasıyla arz-talep oynaklığı ile sabit sermayenin yenilenmesinden kaynaklanan çevrimsel krizler; 45-60 yıllık periyotlarda ortaya çıkan kar oranlarının düşme eğilimiyle karakterize edilen tarihsel krizler olarak sınıflandırılır ${ }^{3}$. Bu bağlamda çalışmanın kısıtlarından biri üçüncü tarihsel kriz olarak kabul edilen 1970’li yılların krizidir. 1970'li yılların tarihsel krizi, esas itibariyle krizi telafi edici mekanizmalar yoluyla 2008 yılına kadar ertelenebilmiştir. Neoliberalizm ve bununla bağlantılı olan çeşitli uygulama biçimleri de söz konusu krizi telafi etmek veya tersine çevirmek amacıyla ileri sürülen mekanizmaların bütünü olarak ele alınmaktadır.

Çalışmanın amacı, neoliberalizm adı altında uygulanmaya konan krizden çıkış politikaları/stratejilerinin işçi sınıfının çalışma ilişkilerini ve yaşam koşullarını ne düzeyde

\footnotetext{
${ }^{2}$ Krizsizliğin kapitalizm ile bağdaşmadığı konusunda fikri ortaklıklar olmasına rağmen kapitalizmin krizlerini açıklama noktasında kuramsal bir enflasyonun bulunduğunu söyleyebiliriz. Klasik ortodokside kriz, genel itibariyle arızi, geçici ve dışsal ya da doğal şokların yol açtığı, olağan durumda meydana gelen bir sapmadır. Bu yaklaşıma göre kriz ancak üretim ilişkileri dışındaki unsurlar tarafından tetiklenir (Güneş lekeleri teorisi, azalan verimler yasası, Roma Kulübü tarzı yaklaşımlar gibi). Keynesyenler'e göre kriz, eksik tüketimden ya da talep yetersizliğinden kaynaklanmaktadır. Klasik ortodoksinin görünmez elin sağladığı tam otomatik denge mekanizmasının tersine kamu müdahalesinin (görünür elin) olmadığı bir ekonomik işleyişte krizin kaçınılmaz olacağı ortaya konulmaktadır. Schumpeter'de iktisadi krizin, kapitalizm için kaçınılmaz bir unsur olduğunu, “'yaratıcı yıkım' 'tezi çerçevesinde ortaya koyar. Post-Keynesyenler'in kriz çözümlemesi; belirsizlik, asimetrik bilgi sorunu ve temelde finansal piyasalardaki aksaklıklara dayanmaktadır. Monetaristler krizi, kamunun aktif müdahalesi ile petrol krizi gibi dışsal şokların yanında para politikalarının etkinsiz kullanımı temelinde ele almaktadır. Kriz teorileri üzerindeki enflasyonist etkinin, Marksist kriz teorileri için de geçerliliği bulunmaktadır. Marksizm içinde beş temel kriz yaklaşımının olduğu ileri sürülmektedir. Bunlar; üretim anarşizmi, orantısızlık, eksik tüketim, kar sıkışması, kar oranlarının düşme eğilimi yasası olarak sıralanmaktadır (Clarke, 2007; Satlıgan ve Savran, 2009; Savran, 2013).

${ }^{3}$ Ticaret döngüleri ya da iş çevrimleri yaklaşımlarının tarihsel kökleri 19.yy’la kadar uzanmaktadır. C. Juglar (1862), 7-11 yıllık sabit sermayenin yenileme çevrimini ele almış, J. Kitchen (1920)'de 3-5 yıllık arz-talep oynaklığı temelindeki çevrimlerle ilgilenmiştir. N. Kontratieff (1925) ise, ABD için 1789-1920 dönemleri arasındaki fiyat hareketlerini inceleyerek 45-60 yıllık uzun dalga teorisinin öncüsü olarak bilinmektedir.
} 
etkilediğini tespit etmektir. Zira burjuvazi, krizi bertaraf etmek ve karlılıklarını restore etmek amacıyla yüzünü ilk olarak işçi sınıfi ile ilişkilerini düzenlemeye çevirmekte, sömürü koşullarını derinleştirecek programları gerek değer yasası çerçevesinde gerekse de çıplak zor yoluyla uygulamaya gitmektedir.

Böylece çalışmanın takip eden bölümünde kavramsal çerçeve sunulmakta, neoliberalizmle birlikte çalışma ilişkilerinde yaşanan gelişmeler değerlendirmekte ve çeşitli istatistiklere yer verilmektedir. Çalışmanın bir diğer alt başlığında, literatür taraması yapılmaktadır. Son bölümde ise, kapitalizmin merkez ülkeleri olarak kabul edilen G-7 ülkeleri için 1970 yılı sonrası döneme ait olan verimlilik, sendikalaşma yoğunluğu ve emek geliri değişkenleri arasındaki ilişki, yapısal kırılmalı panel veri analizi test yöntemleri yardımıyla araştırılmaktadır. Çalışma, sonuç ve değerlendirme bölümüyle tamamlanmaktadır.

\section{NEOLIBBERALIZM ÇERÇEVESINDE VERIMLILIIK, SENDÍKALAŞMA YOĞUNLUĞU ve ÜCRETLİ EMEK İLIŞKISSI}

1970’li yılların ortalarında ortaya çıkan yapısal kriz, sermayenin döngüsel hareketinin ve yeniden üretim sürecinin sekteye uğradığ 1 bir tarihsel momentuma işaret etmektedir. $\mathrm{Bu}$ tarihsel momentum, hem sermayenin yeniden üretim sürecine ilişkin hem de işçi sınıfına yönelik uzun canlılık dönemindeki elde ettiği kazanımlara ilişkin belirli yaptırımların uygulanmaya konulduğu bir dönemdir. İkinci Paylaşım Savaşı'yla birlikte; değersizleşen sermayenin üretimin dışına itilmesi, yeni yatırım olanaklarının oluşması, nükleer enerjinin yanında bilgisayarlı teknolojinin üretime koşulması ve yeni üretim stratejisiyle beraber yüksek kar oranlarının olanakları altında bir altın çağ dönemi başlamıştır. Ancak bu altın çağ (uzun canlılık) dönemi, yalnızca otuz yıl (1945-1975) kadar sürdürülebilmiş ve dünya kapitalizmi yeni bir krizle yüz yüze gelmiştir. Kriz, kapitalist tarzda üretimin olağan işleyişindeki aksaklıkları ifade ederken, sermaye birikim sürecinde tıkanmalar meydana getirmektedir. Sermaye birikim sürecinin istikrarlı bir hal alması ve varlığını sürdürmesi, ancak krize nedene olan dinamikleri ortadan kaldırmak veya ertelemekle mümkündür. Ancak, kriz olgusu sermayeler için salt bir çöküş ve yıkım hali değildir. Kapitalizmin gerçek rekabet koşulları altında kriz, aynı zamanda büyük ölçekli sermayeler için yeni bir canlanma, genişleme, yoğunlaşma ve merkezileşmenin de adıdır. 
1970’li yıllarda meydana gelen yapısal kriz, kendinden önceki uzun canlılık dönemini sonlandıran bir karlılık krizi olarak açığa çıkmıştır. Sermayelerin organik bilişimindeki artışın getirdiği toplumsal üretici güçlerdeki devasa gelişmelerin genelleşmesi yani toplumsal sermaye tarafından üretim sürecine uygulanabilmesi kar oranlarının düşüşüne yol açmıştır. Başka bir ifadeyle, üretim sürecinin değer yaratan tek öznesi olan canlı emeğin (değişen sermayenin) yerini değer yaratmayan ölü emeğin (değişmez sermayenin) alması uzun erimde kar oranlarının kar kitlesi tarafından telafi edilemeyeceği düzeye düşmesine neden olacak ve bu süreçte açık bir karlılık krizinin meydana gelmesine yol açacaktır ${ }^{4}$.

Bununla birlikte, 1970'li yılların ilk yarısında açığa çıkan üçüncü tarihsel kriz dönemine ilişkin yapılan bir dizi ampirik çalışma krizin nedenini gelişmiş kapitalist ülkelerdeki 1960'lı yıllardan itibaren meydana gelen kar oranlarındaki düşüş eğilimine dayandırmaktadır (Vakulabharanam, 2009: 144; Shaikh ve Tonak, 2012). Buna karşın, burjuva ortodoksi tarafından krizin gerçek nedeni olarak petrol fiyatlarındaki yükselmeler (petrol şokları) kabul edilmektedir. Burada, OPEC (Petrol İhraç Eden Ülkeler Örgütü) ülkelerinin petrol fiyatlarını önemli düzeyde yükseltmesinin neden olduğu üretim maliyetlerindeki fiili artışlar kriz koşullarının yalnızca tetikleyici faktörü olmaktadır (Savran, 2013: 35). Kısacası, kar oranlarındaki düşüş eğilimi kapitalizmin tarihsel krizlerinin esas nedeni olarak kabul edilmektedir. Kapitalizmin üçüncü tarihsel krizi olan 1970’li yılların yapısal krizinin özü de kar oranlarındaki düşüş eğiliminden kaynaklanmaktadır. Petrol fiyatlarındaki dönemsel yükselmeler ise ancak krizin tetikleyicisi veya krizin etki gücünü artıran etmen olduğu ileri sürülmektedir.

\footnotetext{
${ }^{4}$ Kapitalizmin altın çağının ardından 1973-74 yıllarında ortaya çıkan yapısal krizle ilgili literatürde önemli tartışmalar söz konusudur. Bu tarihsel kesit, çeşitli biçimlerde yorumlanmaktadır. Bunlar temel hatlarıyla ele alındığında söz konusu yapısal krizin temel nedeni; Glyn, Sutcliffe, Rowthornwk, Boddy, Crotty tarafindan kar sıkışması olarak ifade edilirken (Clarke, 2007); Shaikh (1987), kar oranlarındaki düşüş eğilimi olarak ele almış; Brenner (1987) ise, uluslararası rekabete dayandırmaktadır. Harvey (2005) krizin, kapitalistler açısından iki boyutta anlaşıldığını vurgulamaktadır. Birinci boyutta, güçlü sendikaların varlığının ücretleri yükselttiğini bunun da karları düşürdüğü ileri sürülmekte (kar sıkışması); ikinci boyutta ise ulusal Keynesciliğin ekonomideki rolünün artmasının (kamu müdahalesindeki artışın) piyasada etkinsizlik yaratacağ 1 ve bu dolayımla iktisadi krize neden olduğu vurgulanmaktadır. Yani, krizin her iki boyutunda da sorumlu Keynesci ekonomik politikaların varlığı olduğu kabul edilmektedir. Monetarist yaklaşıma göre ise para politikalarının etkinsiz kullanımı, kriz dinamiklerini tetiklemektedir. Son tahlilde bu çalışmada, Shaikh (1987) ile Shaikh ve Tonak (2012) çalışmaları referans alınarak 1970'li yılların ortalarında cereyan eden yapısal krizin temelleri, kar oranları düşüş eğilimi yasasına dayandırılmaktadır.
} 
Sermayenin, bu yapısal krize karşı, azalan karlılı̆̆ını telafi etmek amacıyla yeni ekonomi politikaları ve üretim stratejileri ortaya koyması gerekmektedir. Bu yaptırımların uygulanma süreci, ekonomik alanın yanında siyasi ve ideoloji alanında da bir dizi mücadeleye sahne olmuştur. Zira kriz anı, sınıfsal mücadelenin en yalın ve sarih görüldüğü andır. Bu bağlamda krizden çıkış stratejisi olarak sermayenin en temel amaçlarından biri ücretli emek ile kurduğu ilişkileri yeniden düzenlemek ve dönüştürmektir. 1970 krizinden sonra uygulanmaya konulan krizden çıkış stratejisinin ve ekonomi politikasının adının neoliberalizm olduğu bilinmektedir. Grafik 1'de 1869-2007 dönemleri arası kar oranlarının düşme eğilimiyle birlikte meydana gelen tarihsel krizlerin ve karlılığın restorasyonu için geliştirilen mekanizmaların bir manzarası sunulmaktadır.

\section{Grafik 1. 14 Gelişmiş Ülkenin Kar Oranları Ortalaması (1869-2007)}

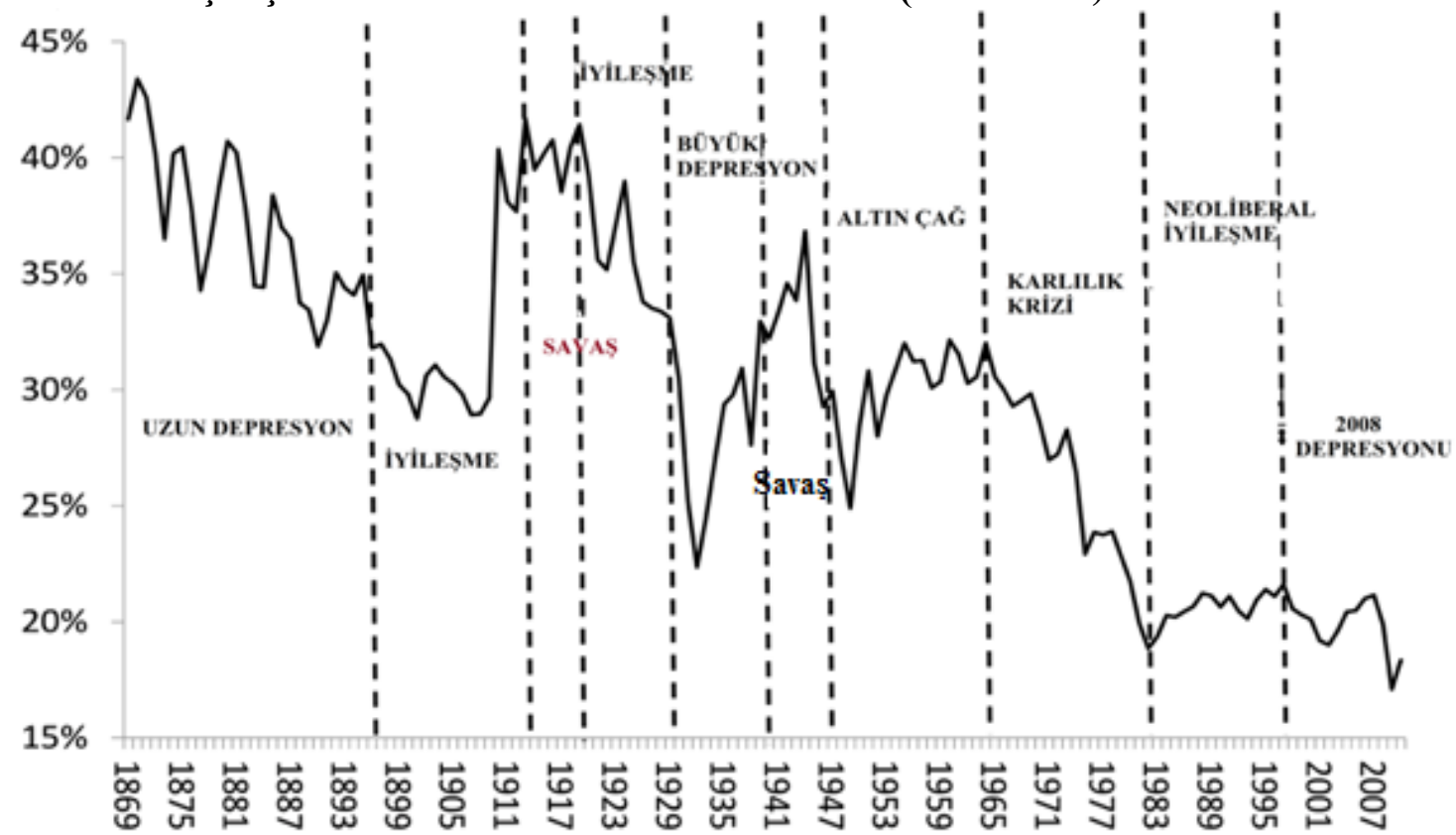

Kaynak: Michael Roberts tarafından düzenlenen veri setinden alınmıştır. Bu konuda ampirik düzeyde farklı çalışmalar mevcuttur.(Bkz. Vakulabharanam, 2009: 144; Shaikh ve Tonak, 2012).

Grafik 1'de görüldüğü üzere, kapitalizmin 19. yüzyılın son çeyreğindeki Uzun Depresyon'dan çıkışı için insanlığın ödediği bedel emperyalizm ve onun çeşitli coğrafyalardaki barbarlığı olmuştur. 20. yüzyılın Büyük Depresyonu, ancak faşizm, İkinci Dünya Savaşı ve Holokost yaşandıktan sonra çözüme kavuşturulabilmiştir (Savran, 2013). 1970’li yılların krizinde ise neoliberal politikalar uygulanarak kriz çözüme kavuşturulmak ya da geciktirilmek 
istenmiştir ${ }^{5}$. Ancak geciktirilen karlılık krizi, içinde daha büyük çelişkileri biriktirerek 2008 yılı itibariyle dünya ekonomisini daha derinden etkilemiş ve onarılmaz yaralar açmıştır. Son tahlilde; 2008 küresel kriziyle birlikte, yaklaşık kırk yıl önce meydana gelen yapısal krizin bertaraf edilebileceğine inanılan ekonomik ve siyasal politikaların topyekûn iflas ettiği, günümüz dünyasındaki gelişmeler temelinde açıkça görülmektedir.

Kapitalizmin tarihsel kriz uğraklarını ve söz konusu krizlerden çıkış mekanizmalarının ulusal ekonomilere etkisini gösteren en temel göstergelerden birinin kuşkusuz ekonomik büyüme oranlarının olduğu söylenebilir. Grafik 2'de G-7 ülkeleri için 1900-2016 dönemleri arası ekonomik büyüme oranları sunulmaktadır.

\section{Grafik 2. G-7 Ülkelerinde 1900-2016 Yılları Arası Ekonomik Büyüme Oranları (\%)}

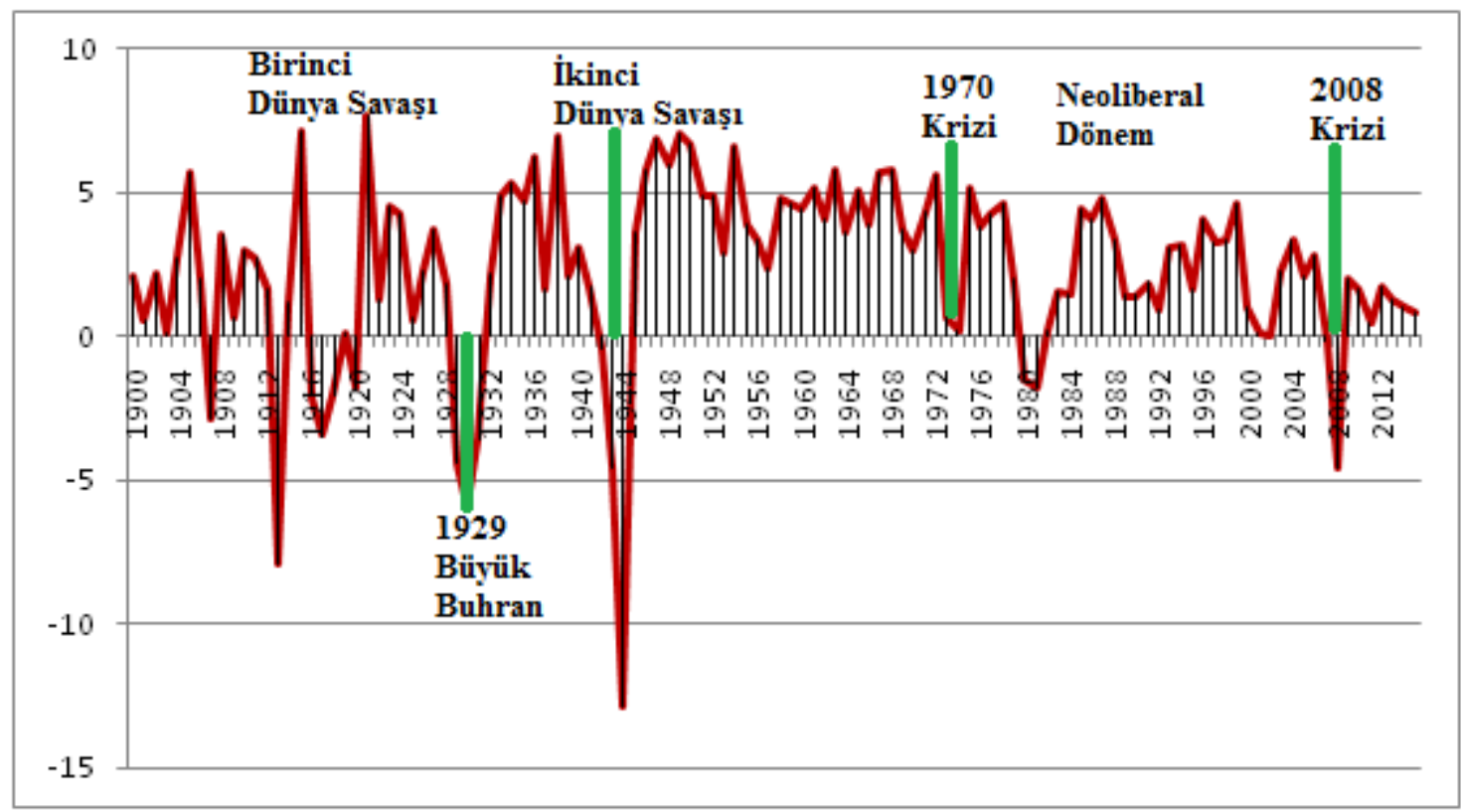

Kaynak: Maddison Historical Statistic ile Dünya Bankası veri setinden derlenmiştir. Grafik alanının dışında kalan diğer verilere göre, G-7 ülkeleri için ekonomik büyüme oranları 2013 yılında \%1.06, 2014 yılında \%1.63, 2015 y1lında \%1.54, 2016 y1lında \%1.40, 2017 y1lında \%2.20, 2018 y1lında \%1.57 olarak tespit edilmektedir.

\footnotetext{
${ }^{5}$ Kapitalizmin 1970'li yıllarda ortaya çıkan kar oranlarının düşme kriziyle birlikte burjuvazi krizden çıkış yolunu 1980'li yıllarda post-fordist tarza yeniden yapılanmakta bulmuştur. Buna ilaveten, KİT'lerin özelleştirilmesi, eğitim ve sağlık gibi kamusal hizmetlerin sermayenin denetimine bırakılması, Bretton Woods'un lağvedilmesinin ardından serbest kur rejimine geçiş ve bununla beraber finansallaşmanın hız kazanması, korumacı politikaların sonlandırılarak fiyat denetimlerinin ortadan kaldırılması, küreselleşme perdesi altında sermaye serbestisinin sağlanması, sınıfsal kazanımların geriletilmesi, sendikaların güçten düşürülmesi, sendikal örgütlülüğün zayıflaması ve dolayısıyla emek sürecinin esnekleştirilmesi kısaca sermayenin bir bütün olarak işçi sınıfına yönelik taarruzu sermayenin söz konusu tarihsel eğiliminin genel karakteristiği olarak ifade edilmektedir.
} 
Grafik 2'de G-7 ülkeleri için sunulan ekonomik büyüme oranlarına göre; özellikle kriz dönemlerinde ekonomik büyüme rakamları çöküş halindeyken, sermayenin çıkarları doğrultusunda krizi restore etmek amaciyla uygulanan strateji ve politikalarla birlikte sermaye birikim çevriminde yeniden bir canlanma sürecinin takip edildiği görülmektedir. 1970'li yılların yapısal krizinin ardından da aynı eğilimlerin ortaya çıtı̆̆ı gözlenmesine rağmen kapitalizmin altın çağındaki ekonomik performanstan oldukça uzak olduğu tespit edilmektedir.

Bununla birlikte, kriz olgusunun teorik çözümlenmesinde olduğu gibi krizleri takip eden yılların çözümlenmesi de genel itibariyle çeşitli teorik açmazlara neden olmaktadır. Neoliberalizme yönelik tartışmalar da, bu teorik kargaşadan nasibini alanlar arasında olduğu ileri sürülmelidir. Neoliberalizm, kimileri tarafından kapitalist gelişmenin ayrı bir aşaması ${ }^{6}$; kimileri tarafından ise yeni bir üretim biçimi şeklinde ifade edilmekte ya da Keynesyen politikaların anti-tezi olarak bütün kötülüklerin anası olarak betimlenmektedir ${ }^{7}$. Fakat, sermayenin hareket yasaları çerçevesinde yapılan tarihsel bir serimde, söz konusu yeniden yapılanma süreçlerinin veya sermaye birikim stratejilerinin mevcut üretim biçimine içre olan tarihsel ve toplumsal koşulların ürünü olduğu ortaya çıkmaktadır .

Burjuvazinin çıkarları ekseninde üretilen, yeniden üretilen ve dönüşüme uğrayan kapitalizm, son 40 y1llık süreçte neoliberalizm olarak tanımlanan bir heyula halinde resmedilmektedir. $\mathrm{Bu}$ dönüşümün temelinde yatan dinamikler belirgin bir şekilde ortaya konulduğunda, Keynesyen politikalar da (uzun canlılık dönemini bitiren) bunalım sonrası uygulanan politikalar da burjuvazinin tarihsel ihtiyaçları doğrultusunda şekillenmiştir. Dolayısıyla "Keynesyenizm” tarihi sürekliliği ve geçerliliği olan bir sistem olmadığına göre,

\footnotetext{
${ }^{6}$ Fine, B., \& Saad-Filho, A. (2017). Thirteen Things You Need to Know About Neoliberalism. Critical Sociology, 43(4-5), 685-706. https://doi.org/10.1177/0896920516655387.

${ }^{7}$ Harvey D. (2008). Yeni Emperyalizm (Çev. Hür Güldü). Everest Yayınları.

${ }^{8}$ Ayşe Buğra (2015: 22)'nın E.P. Thompson'ın “'İngiliz İşçi Sınıfının Oluşumu”'adlı devasa eserine yazdığı giriş yazısında özellikle neoliberalizmle ve bugünle özdeşleştirilen esnekleşmenin, taşeronlaşmanın, fason üretimin ve bir bütün olarak işçi sınıfi ile burjuvazi arasındaki ilişkinin yaklaşık 200 yıl önceki hali şu ifadelerle vurgulanmaktadır: 1830 'da, tipik sanayi işçisi fabrikada çalışmıyordu, ya (zanaatkâr veya "teknisyen" olarak) küçük bir atölyede veya evinde, ya da sokaklarda, şantiyelerde veya rihtımlarda bulduğu geçici işlerde çalışıyordu" (1966: 234). Taşeron iş̧̧ilik veya eve iş verme son derece yaygındı ve sanayi üretimine fabrika dışında boğaz tokluğuna çalışarak katılanlar istisnadan çok kaideyi oluşturuyorlardı. "Taşeron iş̧̧ilik, sanayi devriminin fabrika üretimi ve buhar kadar ayrılmaz bir parçasıydı” (1966: 261). Mayhew'nun (1884), insanın 19. yüzyıl çalışma hayatını bütün canlılığıyla gözünün önüne getirmesine yardım eden ayrıntılı gözlemlerinde belirttiği gibi, düzenli işlerde çalışan iş̧̧ilerin sayısı toplam çalışanların yarısı bile değildi. Geri kalanlar boşta gezip iş olduğunda çalışarak yaşıyorlardı (Thompson 1966: 250).
} 
yok edilmesi için neoliberalizmin veya dışsal bir gücün saldırısına ihtiyaç kalmamıştırişlerliğini kaybettiği anda kendi kendisini imha etmiştir. Marksist yasalar gereği birikimin nihai bir noktada bunalıma dönüşeceği savından yola çıkarak, neoliberal döneme geçişi içeren bunalım dönemi, sermayenin zorunlu bir istikameti olarak nitelenebilir (Polat ve Basmac1, 2018: 126). Grafik 3’te, 1950-2017 dönemleri arası G-7 ülkelerinde emek verimliliğindeki değişim düzeyi gösterilmektedir.

\section{Grafik 3. 1950 Sonrası G-7 Ülkelerinde Emek Verimliliğindeki Değişimin Temposu (ABD Doları, \%)}

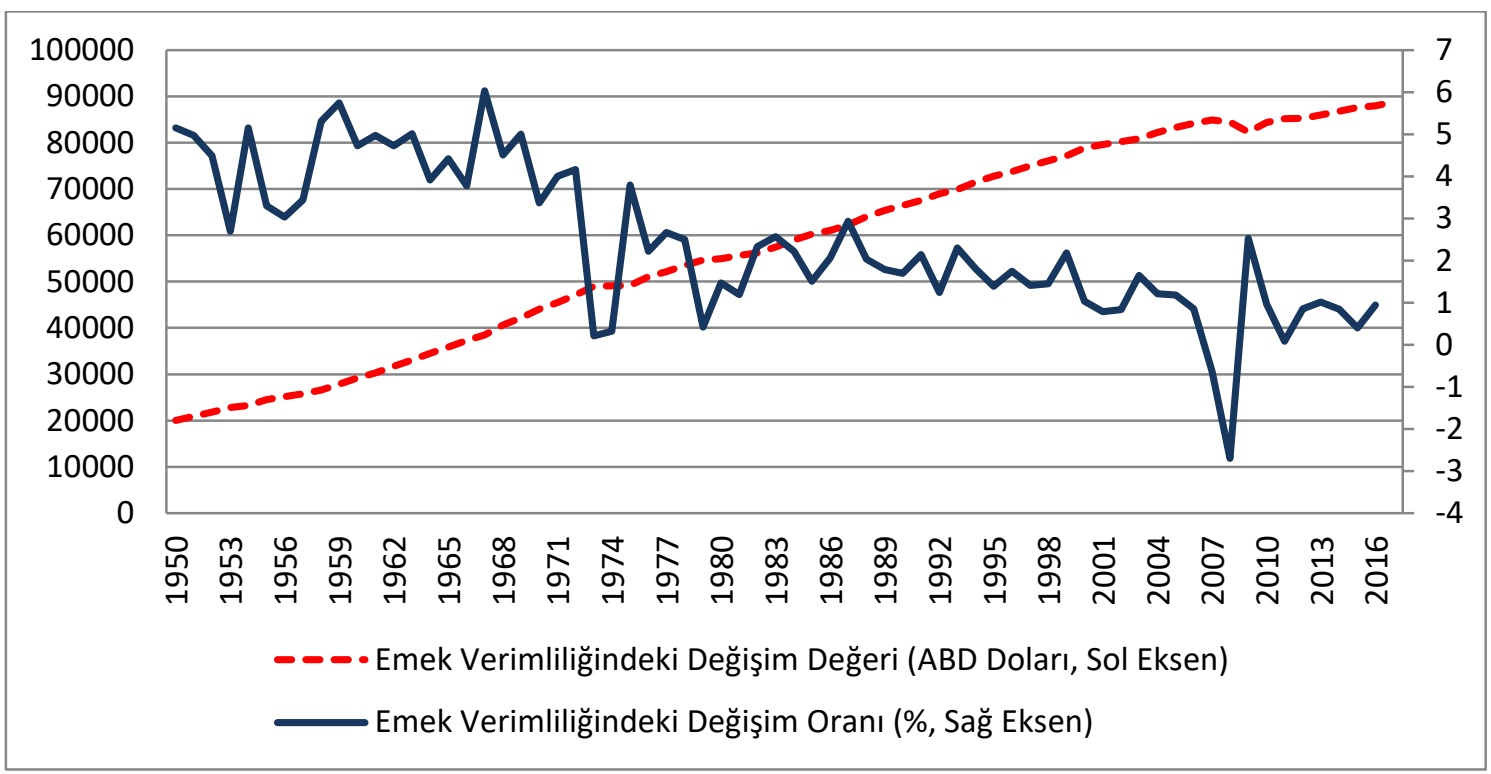

Kaynak: Veriler, Penn World Table version 9.1(https://www.rug.nl/ggdc/productivity/pwt/,)'den elde edilmiş, gerekli hesaplamalar yazar tarafından yapılmıştır.

Grafik 3’te ele alınan dönem incelendiğinde, G-7 ülkelerinde İkinci Paylaşım Savaşı sonrası özellikle Fordizm tipi üretim örgütlenmesi, nükleer enerji (atom enerjisi), bilgisayarlı üretim ve çip teknolojisinin üretim sürecine eklemlenmesiyle beraber emek verimliliğinde mutlak anlamda bir artış gözlenmektedir. Diğer taraftan; söz konusu dönem içerisinde emek verimliliğinde nispi anlamda dalgalı bir seyir izlemesinin yanında 1970 sonrasında düşüş eğiliminde olduğu ve özellikle kriz dönemlerinde bu düşüşün net biçimde açığa çıktığı görülmektedir. 20. yüzyılın ikinci çeyreğinin ardından dünya gündemine oturmuş olan üçüncü sanayi devrimi, üretimde mikro elektronik teknoloji ve otomasyonun kullanıma başlamasıyla tanımlanmıştır. Ayrıca bu dönemde, atom enerjisi, bilgisayar, fiber-optik ve çip gibi mikro elektronik teknolojisine dayalı gelişmeler yaşanmıştır. Dijitalleşme sayesinde, bilgisayar ve 
internetin hızla gelişme göstermesi, beraberinde bilgi işlem ve haberleşme tekniklerinin gelişmesine yol açmıştır (Gehrke vd., 2015: 6). İlk zamanlar ancak bireysel sermayelerin üretime uygulayabildikleri ve kar (artı değer) transferi yapabildiği; dolayısıyla karlarını yükseltebildiği teknolojik yatırımlar, zamanla rekabetin etkisiyle toplumsal sermaye tarafından kullanılabilecek düzeye yayılım göstermesiyle yeni karlılık krizlerine kapı aralamaktadır. Karlılık krizi, sermayeler arasındaki rekabetin koşulladığı bir olgu olarak ortaya çıkmaktadır. Sermayeler arası rekabet, bir yanıyla toplumsal üretkenliği ve emek verimliliğini artırırken bir yanıyla da kriz koşullarını yeniden tesis etmektedir. Marks'ın ifadesiyle; sermayenin önündeki en büyük engel sermayenin kendisidir (Marx, 2011). Grafik 4'te G-7 ülkeleri için 1970-2012 dönemleri arasındaki sendikalaşma yoğunluğu yüzdesel olarak sunulmaktadır.

\section{Grafik 4. G-7 Ülkelerinde Sendikalaşma Yoğunluğu (\%)}

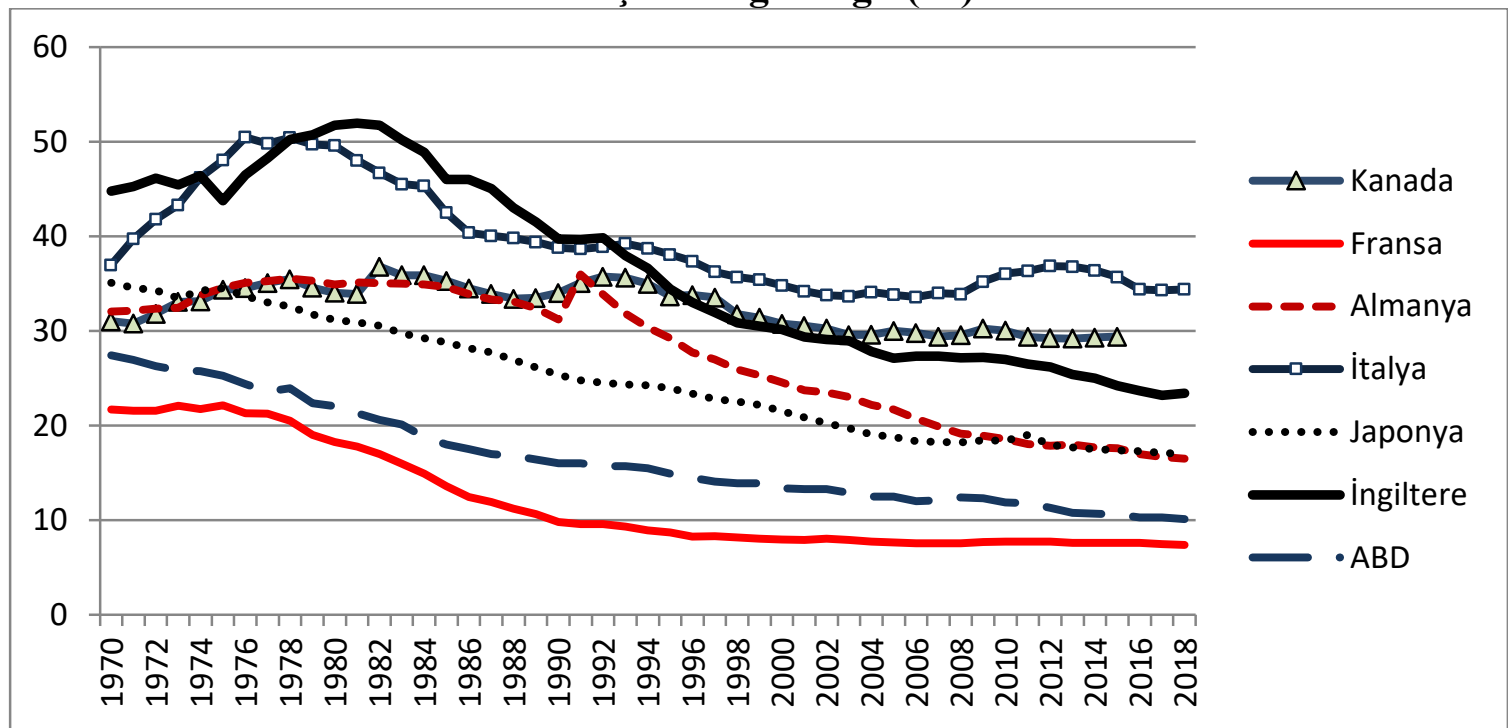

Kaynak: Veriler, Amsterdam Institute for Advanced Labor Studies ile OECD veri setinden derlenmiştir.

Grafik 4’te görüldüğü üzere, sendikalaşma yoğunluğunun özellikle 1980 sonras1 dönemde merkez kapitalist ülkeler için önemli düzeyde düşüşü söz konusudur. Bu süreçte; işçi, sermaye ve devlet arasındaki ilişkilerin yeniden düzenlenmeye başlandığı ve yıllar itibariyle sendikasızlaştırmanın bariz biçimde dayatıldığı gözlenmektedir. Her krizde olduğu gibi 1970 kriziyle de birlikte burjuvazi, ilk olarak emek ile kurduğu ilişkileri dönüşüme uğratmıştır. Sendikasızlaştırmanın bir norm haline getirildiği, toplu sözleşme yasalarının kapsamının daraltıldığı, grevlerin yasaklandığı, esnek ve güvencesiz istihdamın yaratıldığı, 1980 öncesi elde edilen emek gücü kazanımlarının aşamalı olarak ortadan kaldırılması bu sürecin ana damarını oluşturmaktadır. İşçi sınıfi ile burjuvazi arasındaki sınıfsal mücadelede güç 
dengesinin hangi tarafa doğru ağırlık kazandığı burada tarihsel seyrin temel belirleyicisidir. İşçi sınıfına yönelik uygulanan neoliberalizm etiketi altındaki saldırı silsilesi, sermayenin işçi sınıfı üzerindeki hegemonyasını yükseltmeye başladığının göstergesidir. Sendikasızlaşmayla beraber işçilerin toplu pazarlık ve örgütsel güçlerindeki zayıflık, işçi devletlerinin yıkımı sermayenin sınıfsal kazanımlarını hızlandıran ve teşvik eden dinamiklerdir. Grafik 5'te söz konusu tarihsel eğilimin emek gelirleri çerçevesindeki gelişimi verilmektedir.

\section{Grafik 5. G-7 Ülkelerinde Emek Gelirleri(Ortalama, \%)}

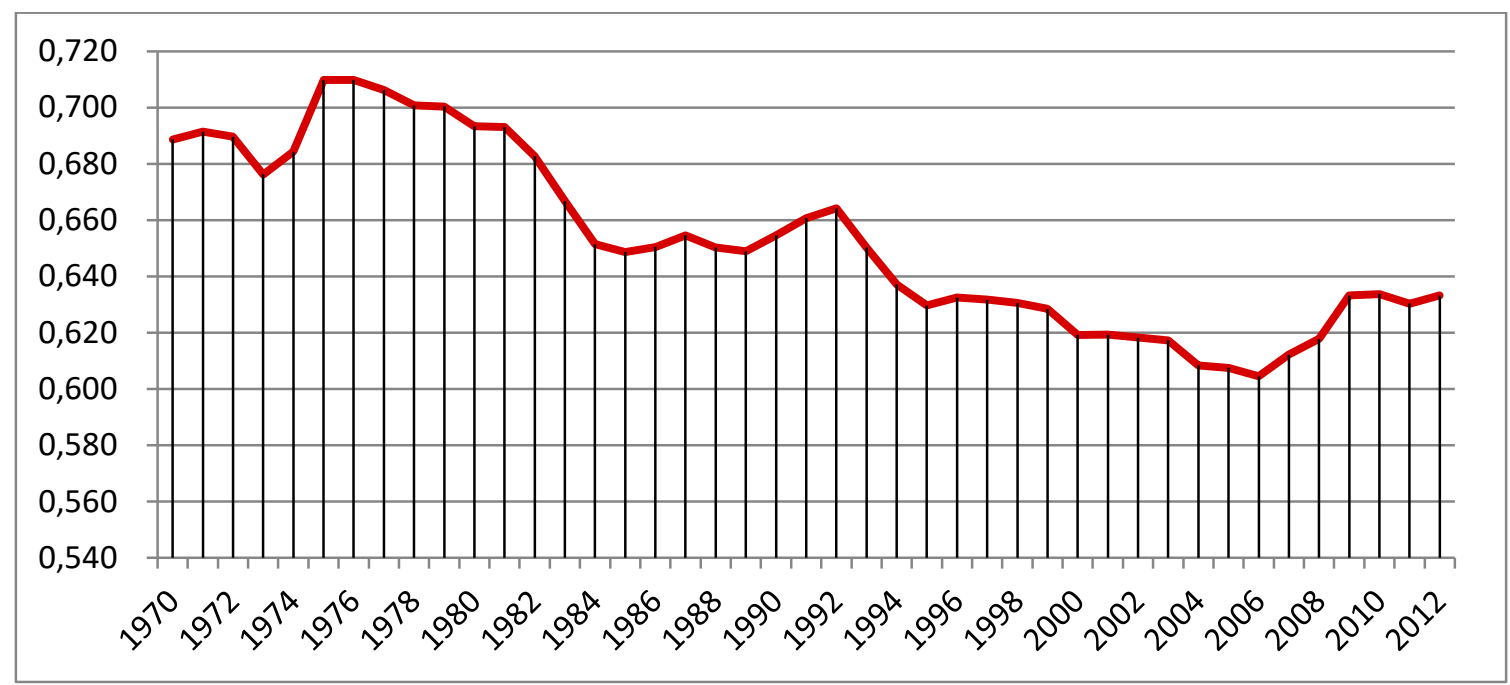

Kaynak: OECD veri setinden derlenmiştir.

Grafik 5'te görüldüğg̈ üzere; sendikal örgütlülük düzeyinin zayıfladığı, toplu pazarlık sisteminin daraltıldığı ve sağlıklı işlemediği, tıkandığı bu dönemde emek gelirlerinin gerilediği ele alınan merkez kapitalist ülkeler için tespit edilmektedir. Son üç grafik kıyaslandığında; 1970 ve özellikle 1980 sonrası daha belirgin hale gelen emek verimliliğindeki önemli düzeydeki artışa karşın sendikalaşma yoğunluğu ve emek gelirlerindeki gerileme, işçi sınıfının toplam üretimden yıllar itibariyle daha düşük pay aldığını göstermektedir. Bu sonuç, fonksiyonel gelir dağılımının emek aleyhine bozulmuş olduğunu, gelir eşitsizliği makasının genişleteceğini ve emek gücünü satarak geçinin toplumsal sınıfın yoksullaştıracağını belirtmektedir. Grafik 6'da G-7 ülkelerinde 1980 sonrası döneme ilişkin en zengin \%1'lik dilimin gelirlerindeki değişim oranları sunulmaktadır. Grafik 5 ile Grafik 6 birlikte değerlendirildiğinde, merkez kapitalist ülkelerde emek gelirlerinin payı yıllar itibariyle düşerken en zengin \%1'lik kesimin aldığı payın da yıllar itibariyle yükseldiği görülmektedir. Sermayedarların işçi sınıfının gelirine rağmen üretilen toplumsal değerden daha fazla pay almaları gelir eşitsizliği (adaletsizliği) sorunsalını 
dünya ekonomisinin gündemine en canlı şekilde koymaktadır. Neoliberal politikaların somutlaştırıldığı 1980 sonrası döneminin genel karakteristiği, sermayenin krizinin işçi sınıfına fatura edilmesi, mülksüzleştirerek birikimin sağlanması, kamusal alanların kar temelli özel girişimlere devredilmesi biçimindedir. Grafik 6' da, G-7 ülkelerindeki en zengin \%1'lik dilimin gelirindeki değişim oranı sunulmaktadır.

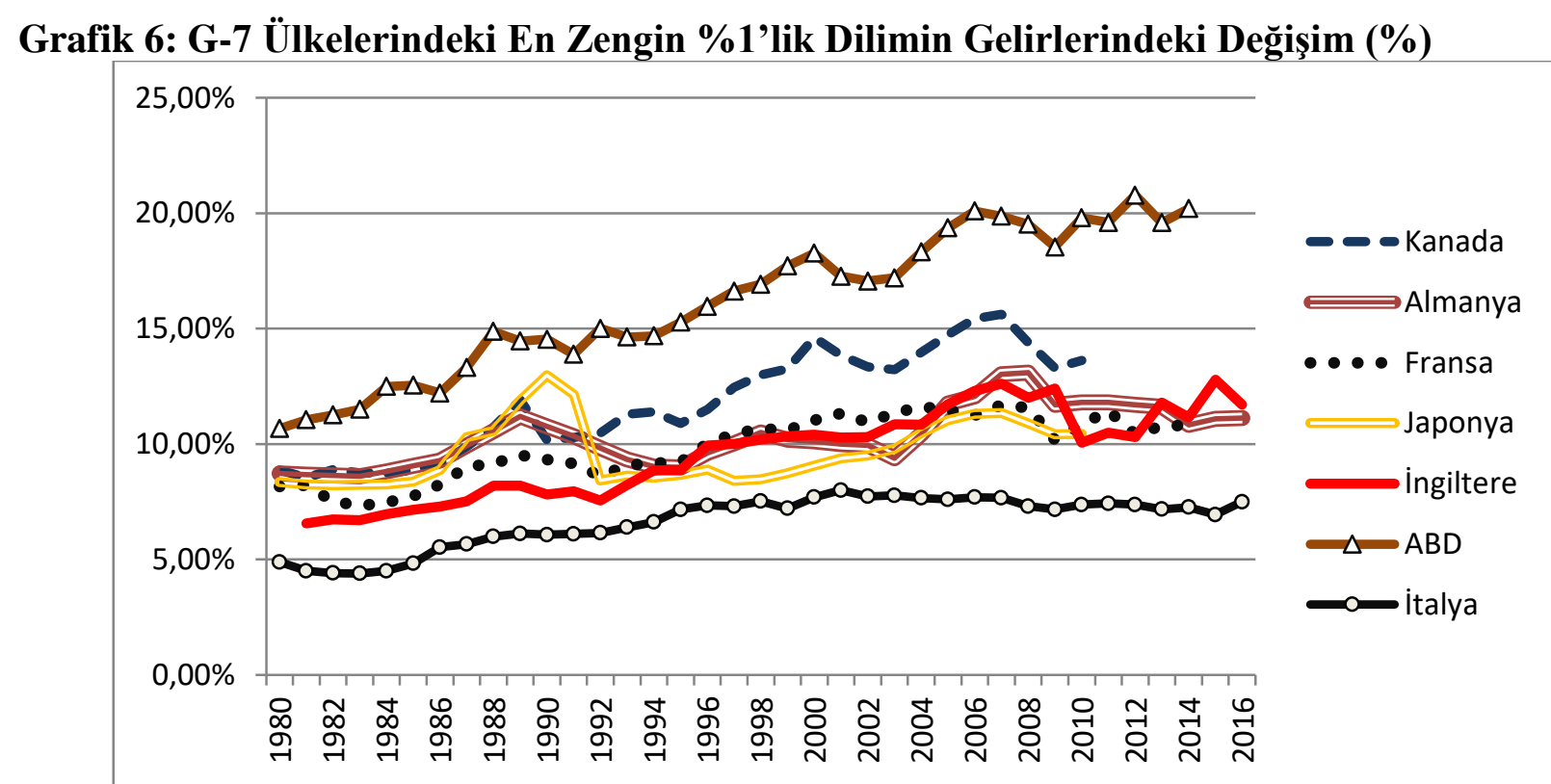

Kaynak: World Wealth and Income Database

\section{LITERATÜR TARAMASI}

Literatür özeti bölümünde; verimlilik, sendikalaşma yoğunluğu ve emek gelirleri arasındaki ilişkiyi inceleyen çalışmaların kısmi bir serimi yapılacaktır. Buna göre Tablo 1'de literatür özeti sunulmuştur.

Tablo 1. Literatür Özeti

\begin{tabular}{|c|c|c|c|c|}
\hline Yazarlar & Kapsam & Dönem & Yöntem & \multicolumn{1}{c|}{ Sonuç } \\
\hline $\begin{array}{c}\text { Fichtenbaum } \\
(2011)\end{array}$ & ABD & 1997-2006 & $\begin{array}{c}\text { Panel Veri } \\
\text { Analizi }\end{array}$ & $\begin{array}{l}\text { Bu çalışmada, sendikalaşma yoğunluğu } \\
\text { ile emek gelirleri arasında pozitif yönlü } \\
\text { bir ilişkinin varlığ tespit edilmiştir. }\end{array}$ \\
\hline
\end{tabular}




\begin{tabular}{|c|c|c|c|c|}
\hline $\begin{array}{l}\text { Wallace vd. } \\
\text { (1999) }\end{array}$ & $\mathrm{ABD}$ & 1949-1992 & $\begin{array}{l}\text { Zaman Serisi } \\
\text { Analizi }\end{array}$ & $\begin{array}{l}\text { Araştırma sonucuna göre, emek-sermaye } \\
\text { çelişkisinin görece daha uzlaşır olduğ } \\
\text { dönemlerde grev sayıları ile } \\
\text { sendikalaşma yoğunluğundaki artış emek } \\
\text { gelirlerini pozitif etkilemektedir. Ancak, } \\
\text { emek-sermaye çelişkisinin derinleştiği } \\
\text { süreçlerde grev ve sendikalaşma } \\
\text { yoğunluğu emek gelirlerini negatif } \\
\text { yönde etkilemektedir. }\end{array}$ \\
\hline $\begin{array}{l}\text { Barth vd. } \\
\text { (2017) }\end{array}$ & Norveç & 2001-2012 & $\begin{array}{l}\text { Doğrusal Olasilık } \\
\text { Modeli }\end{array}$ & $\begin{array}{l}\text { Norveçli firmalarda sendikalaşma } \\
\text { yoğunluğundaki artı̧̧ hem emek } \\
\text { verimliliğini hem de ücret gelirlerini } \\
\text { artırdığı tespit edilmiştir. }\end{array}$ \\
\hline $\begin{array}{c}\text { Barrades } \\
(2019)\end{array}$ & $\begin{array}{l}27 \mathrm{AB} \\
\text { Ülkesi }\end{array}$ & $1995-2013$ & $\begin{array}{l}\text { Panel Veri } \\
\text { Analizi }\end{array}$ & $\begin{array}{l}\text { Finansallaşma ve neoliberal politikaların } \\
\text { AB Ülkelerinde emek gelirleri payını } \\
\text { düşmesine neden oldukları ileri } \\
\text { sürülmüşstur. Teknolojik gelişmelerin de } \\
\text { emek gelirleri payını düşürdüğ̈ü } \\
\text { sonucuna ulaşılmıştır. }\end{array}$ \\
\hline $\begin{array}{l}\text { Bentolila ve Saint } \\
\text { Paul } \\
\text { (2003) }\end{array}$ & $\begin{array}{l}12 \text { OECD } \\
\text { Ülkesi ve } 13 \\
\text { Endüstri }\end{array}$ & $1972-1993$ & $\begin{array}{c}\text { Panel } \\
\text { Ekonometrisi }\end{array}$ & $\begin{array}{l}\text { Birçok kontrol değişkenin kullanıldı̆̆ } \\
\text { çalı̧mada elde edilen en temel sonuç } \\
\text { sınıf çatışmaları ile emek gelirleri } \\
\text { arasında herhangi bir ilişkinin } \\
\text { bulunmadığıdır. }\end{array}$ \\
\hline $\begin{array}{l}\text { Carter } \\
(2007)\end{array}$ & $\begin{array}{l}15 \text { Yüksek } \\
\text { Gelirli Ülke }\end{array}$ & 1963-1996 & $\begin{array}{c}\text { Panel } \\
\text { Ekonometrisi }\end{array}$ & $\begin{array}{l}\text { Elde edilen bulgulara göre; sendikalaşma } \\
\text { yoğunluğu ile emek gelirleri arasında } \\
\text { anlamlı bir ilişki yoktur. }\end{array}$ \\
\hline $\begin{array}{l}\text { Macpherson } \\
\quad(1990)\end{array}$ & $\begin{array}{l}\text { ABD İmalat } \\
\text { Endüstrisi }\end{array}$ & $\begin{array}{l}\text { 1973-1975; } \\
\text { 1983-1985 }\end{array}$ & $\begin{array}{c}\text { Yatay Kesit } \\
\text { Analizi }\end{array}$ & $\begin{array}{l}\text { Sendikalaşma yoğunluğu ve büyüklüğü } \\
\text { ile emek gelirleri arasında pozitif yönlü } \\
\text { bir ilişki tespit edilmiştir. }\end{array}$ \\
\hline $\begin{array}{l}\text { Sharpe vd. } \\
\text { (2008) }\end{array}$ & $\begin{array}{l}\text { Kanada ve } \\
\text { OECD } \\
\text { Ülkeleri }\end{array}$ & $1980-2005$ & $\begin{array}{l}\text { Regresyon } \\
\text { Analizi }\end{array}$ & $\begin{array}{l}\text { Elde edilen bulgulara göre; Kanada'da } \\
1980-2005 \text { yılları arası emek verimliliği } \\
\% 37 \text { artmasına rağmen medyan reel } \\
\text { kazançlarda aynı düzeyde bir artış } \\
\text { olmamış ve tıkanıklık tespit edilmiştir. }\end{array}$ \\
\hline $\begin{array}{l}\text { Asaleye vd. } \\
\text { (2017) }\end{array}$ & Nijerya & $1980-2015$ & $\begin{array}{c}\text { Zaman Serisi } \\
\text { Analizi-ARDL }\end{array}$ & $\begin{array}{l}\text { ARDL sonucuna göre, emek verimliliği, } \\
\text { istihdam ve reel ücretler arasında uzun } \\
\text { dönemli ilişki söz konusudur. Ayrıca, } \\
\text { çıtı miktarındaki artış hem kısa vade } \\
\text { hem de uzun vadede çalışanların } \\
\text { kazancına dönüşmediği bulgulanmıştır. }\end{array}$ \\
\hline
\end{tabular}




\begin{tabular}{|c|c|c|c|c|}
\hline $\begin{array}{c}\text { Tsoku ve } \\
\text { Matarise } \\
(2014)\end{array}$ & $\begin{array}{l}\text { Güney } \\
\text { Afrika }\end{array}$ & $1970-2011$ & $\begin{array}{l}\text { Zaman Serisi } \\
\text { Analizi }\end{array}$ & $\begin{array}{l}\text { Emek verimliliği, reel ücret ve işsizlik } \\
\text { oranları arasında uzun dönemde pozitif } \\
\text { yönlü bir ilişki tespit edilmiştir. Ancak } \\
\text { Granger nedensellik test sonucuna göre; } \\
\text { reel ücretlerden emek verimliliğine ve } \\
\text { emek verimliliğinden reel ücretlere } \\
\text { doğru herhangi bir nedensellik ilişkisini } \\
\text { saptanmamıştır. }\end{array}$ \\
\hline
\end{tabular}

\section{AMPIRIK ANALIZ}

Bu çalışmada; verimlilik ile sendikalaşma yoğunluğunun emek gelirleri üzerindeki etkileri, kapitalizmin merkez ülkeleri olarak kabul edilen G-7 ülkeleri için 1970-2012 dönemi verileri kullanılarak, yatay kesit bağımlılığını ve çoklu yapısal kırılmaları göz önünde bulunduran panel veri analizi yöntemleriyle incelenmiştir. İncelenen değişkenler, oransal (\%) olarak modele dahil edilmiştir. Araştırmada kullanılan verimlilik değişkenine ait istatistikler Penn World Table version 9.1 ve OECD veri setinden, emek gelirleri değişkenine ait istatistikler OECD'den; sendikalaşma yoğunluğu değişkenine ilişkin istatistiklerden ABD'nin 1980-1990 dönemine gösteren veriler Bureau of Labar Statistics (BLS)'den, sendikalaşma yoğunluğunu temsil eden diğer istatistikler ise University of Amsterdam, Amsterdam Institute for Advanced Labor Studies veri setinden derlenmiştir. Çalışmadaki analizler, Gauss 10 programı ve bu program için geliştirilmiş kodlar kullanılarak gerçekleştirilmiştir.

Tablo 2. Verimlilik, Sendikalaşma Yoğunluğu ve Ücretli Emek İlişkisine Yönelik Tanımlanan Değişkenler

\begin{tabular}{|c|c|}
\hline SERI் & SERILERİN AÇIKLANMASI \\
\hline EV & Emek Verimliliği (\%) \\
\hline SY & Sendikalaşma Yoğunluğu (\%) \\
\hline EG & Ücret Gelirlerinin GSYİH İçindeki Payı (\%) \\
\hline
\end{tabular}

Analiz için kullanılan ekonometrik modeller aşağıdaki gibidir;

$$
\text { Model 1: } E G_{i t}=a_{0 i}+a_{1 i} S Y+u_{i t}
$$

Model 2: $E G_{i t}=B_{0 i}+B_{1 i} E V+z_{i t}$

Modellerdeki $a_{0 i}$ ile $B_{0 i}$, sabit terim; $u_{i t}$ ve $z_{i t}$, hata terimleri ifade etmektedir. 


\subsection{Yatay Kesit Bağımlılığının Test Edilmesi}

Zaman ve yatay kesit boyutlarının, yatay kesit bağımlılı̆̆ (YKB) analizinde önemli bir yeri vardır. Çünkü YKB analizi yapılırken zaman ve yatay kesit boyutları kıstas alınır; analiz bu doğrultuda gerçekleştirilir. Zaman ve yatay kesit boyutlarına göre şekillenen analizler şu şekildedir. Berusch Pagan (1980) tarafından geliştirilmiş CDLM1 testi, zaman boyutunun yatay kesit boyutundan büyük olduğu durumlarda; Pesaran (2004) tarafından geliştirilmiş CDLM2 testi, zaman boyutunun yatay kesit boyutuna yakın yahut küçük olduğu durumlarda; yine Pesaran (2004) tarafından geliştirilmiş CDLM testi, yatay kesit boyutunun zaman kesiti boyutundan büyük olduğu durumlarda kullanılmaktadır. YKB testinin hipotezleri aşağıdaki gibidir:

$\boldsymbol{H}_{\mathbf{0}}$ : Seriler arasında yatay kesit bağımlılı̆̆ yoktur;

$\boldsymbol{H}_{\mathbf{1}}$ : Seriler arasında yatay kesit bağımlılı̆̆ı söz konusudur.

Gerekli analizler gerçekleştirildikten sonra olasılık değeri 0,01,0,05 ve 0,10'dan küçük olduğunda, $\% 1, \% 5, \% 10$ anlamlılık düzeyi için $H_{0}$ hipotezi reddedilmektedir. Bu durumda, panelde kullanılan değişkenlerde YKB'nin varlığı kabul edilmektedir (Pesaran vd., 2008). Tablo 3'te YKB test sonuçları sunulmuştur.

Tablo 3. Yatay Kesit Bağımlılığı Test Sonuçları

\begin{tabular}{|c|c|c|c|c|}
\hline $\begin{array}{c}\text { Modeller } \\
\text { Değişkenler }\end{array}$ & $\begin{array}{c}\text { Breusch-Pagan } \\
\text { LM1 }\end{array}$ & $\begin{array}{c}\text { Pesaran Scaled } \\
\text { LM2 }\end{array}$ & Pesaran CD & $\begin{array}{c}\text { Bias Adjusted CD } \\
\text { Test }\end{array}$ \\
\hline EV & 46.244 & 3.895 & -4.275 & 7.287 \\
& $(0.001)$ & $(0.000)$ & $(0.000)$ & $(0.000)$ \\
\hline SY & 55.049 & 5.254 & -3.022 & 11.983 \\
& $(0.000)$ & $(0.000)$ & $(0.001)$ & $(0.000)$ \\
\hline EG & 47.832 & 4.140 & -4.180 & 8.715 \\
& $(0.001)$ & $(0.000)$ & $(0.000)$ & $(0.000)$ \\
\hline Model 1 & 495.572 & 24.243 & 2.799 & 166.235 \\
& $(0.000)$ & $(0.000)$ & $(0.003)$ & $(0,000)$ \\
\hline Model 2 & 535.546 & 26.823 & 11.897 & 251.417 \\
& $(0.000)$ & $(0.000)$ & $(0.000)$ & $(0.000)$ \\
\hline
\end{tabular}

Not: Tabloda olasılık değerleri parantez içinde gösterilmiştir. 
Tablo 3'te yatay kesit bağımlılı̆g temelinde LM1, LM2, CD, LMadj testleri kullanılmıştır. Bu sonuca göre, emek verimliliği (EV), sendikalaşma yoğunluğu (SY), emek gelirleri (EG), Model 1 ve Model 2 değişkenlerine ilişkin tespit edilen olasılık değerleri 0,05'ten küçük olduğu için, $\mathrm{H}_{0}$ hipotezleri \%1 anlamlılık düzeyinde reddedilerek serilerde ve eş bütünleşme denkleminde YKB'nin varlığına karar verilmiştir. Bu sonuç, analiz konu edilen ülkeler arasında meydana gelen herhangi bir şokun diğer ülke ekonomilerini de etkilediğini işaret etmektedir. Böylece politika yapıcılar diğer ülkelerde meydana gelen herhangi bir şoku veya şokları göz önünde bulundurmalıdır. YKB testi sonuçlarına göre; analizin ileri aşamasında yeni (ikinci) nesil panel testleri kullanılmalıdır.

\subsection{Panel Birim Kök Analizi}

YKB'ye uygun olarak kullanılan testler, yeni nesil (ikinci nesil) birim kök testleri olarak tanımlanmaktadır. Panelde kullanılan serilerin durağanlık sınanması, Pesaran(2007) tarafından geliştirilen ikinci nesil birim kök testlerinden olan CADF test yöntemi ile araştırılmıştır. Tablo 4'te CADF panel birim kök test sonuçları sunulmuştur.

Tablo 4. CADF Panel Birim Kök Testi Sonuçları

\begin{tabular}{|c|c|c|c|c|c|c|}
\hline \multicolumn{7}{|c|}{ Test Istatistiği } \\
\hline Ülkeler & EV & $\Delta \mathrm{EV}$ & SY & $\Delta S Y$ & EG & $\Delta \mathrm{EG}$ \\
\hline Kanada & -1.57 & $-4.57^{*}$ & -0.92 & $-4.97 * *$ & -3.46 & $-5.49 *$ \\
\hline Fransa & -0.75 & $-6.41^{*}$ & -1.09 & -1.56 & -2.25 & -2.68 \\
\hline Almanya & -3.12 & $-4.30 * *$ & -1.32 & $-5.05^{*}$ & -3.56 & $-5.83^{*}$ \\
\hline İtalya & -1.62 & $-4.05 * *$ & -2.49 & -2.40 & -1.53 & $-3.83 * *$ \\
\hline Japonya & -0.73 & -3.59 & -2.33 & $-4.40 * *$ & -2.64 & $3.79 * *$ \\
\hline ABD & -3.07 & $-5.04^{*}$ & -3.35 & -3.20 & $-4.41 * *$ & $-5.97^{*}$ \\
\hline İngiltere & -0.72 & -2.62 & $-3.99 * *$ & $-5.17^{*}$ & -1.24 & $-5.12^{*}$ \\
\hline Panel (CIPS) & -1.65 & $-4.37 *$ & -2.21 & $-3.82 *$ & -2.73 & $-4.67^{*}$ \\
\hline
\end{tabular}

Not: Pesaran (2007) çalışmasına referansla sabit ve trendli modelde CADF testi için kritik değerler; $\% 1$ ve $\% 5$ anlamlılık düzeyinde sırasıyla -4.49 ve -3.78 , CIPS testi için; -3.06 , ve -2.84 'dür. $\Delta$, fark operatörü olup değişkenin farkının alındığını göstermektedir. * ve ** sembolleri sırasıyla $\% 1, \% 5$ ve $\% 10$ anlamlılık düzeyinde serilerin durağan olduğunu göstermektedir.

Tablo 4'teki panel birim kök testi sonuçlarına göre, panelin geneli için serilerin düzey seviyesinde durağan olmadıkları, ancak birinci fark seviyesinde durağanlaştığı tespit edilmişsir. Panelin geneli için serilerin tamamı I(1) olduğundan panel eşbütünleşme analizine geçilmesi mümkündür. Zira, gerek zaman serisi gerekse de panel veri ekonometrisinde eşbütünleşme analizine geçebilmenin ön koşulu serilerin birinci fark I(1) seviyesinde durağan olmasıdır. 


\subsection{Eş-Bütünleşme Katsayılarının Homojenliğinin Test Edilmesi}

Panel eş bütünleşme analizinde, eşbütünleşme katsayılarının homojen olup olmadığı bu test yardımıyla analiz edilir. Böylece homojenlik testi sonuçları, Tablo 5'te sunulmuştur.

Tablo 5. Pesaran ve Yamagata (2008) Homojenite Testi Sonuçları

\begin{tabular}{|c|c|c|c|}
\hline & & Test İstatistiği & Olasılık Değeri \\
\hline \multirow{2}{*}{ Model 1 } & $\widetilde{\Delta}$ & -0.216 & 0.585 \\
\cline { 2 - 4 } & $\widetilde{\Delta}_{d j}$ & -0.223 & 0.588 \\
\hline \multirow{2}{*}{ Model 2 } & $\widetilde{\Delta}$ & 1.842 & 0.033 \\
\cline { 2 - 4 } & $\widetilde{\Delta}_{d j}$ & 1.908 & 0.028 \\
\hline
\end{tabular}

Tablo 5'te elde edilen bulgulara göre, Model 1 için hesaplanan homojenite testinin olasılık değerleri 0,05 'ten büyüktür. Buna göre, $\mathrm{H}_{0}$ hipotezi kabul edilmiş, eş bütünleşme denklemine ait sabit ve eğim katsayısı homojen olduğu bulgulanmıştır. Bu sonuç, Model 1 için uygulanacak analizlerin ileri safhasında panel istatistiklerinin temel alınmasını gerekli kılmış, eş bütünleşme yorumlarının geçerliliğini ve güvenilirliğinin panelin geneli için yapıldığ takdirde tutarlı olabileceğini işaret etmektedir. Model 2 için hesaplanan homojenite testinin olasıl1k değerlerinin 0,05 'ten küçük olduğuna ulaşılmıştır. $\mathrm{Bu}$ sonuca göre, eşbütünleşme denklemine ait sabit ve eğim katsayısı homojen değildir. Dolayısıyla Model 2 için ülke birimlerini göz önüne alarak yapılacak analiz, daha güvenilir ve tutarlı sonuçlar üretmektedir (Pesaran and Yamagata, 2008).

\subsection{Yapısal Kırılmalı Panel Eşbütünleşme Analizi}

Eş bütünleşme analizi, ister zaman serisi isterse de panel veri analizi olsun fark etmeksizin serilerin birinci dereceden durağan olması ön şartıyla çalışmaktadır. YKB'nin yanında eş bütünleşme analizinin bir diğer kritik eşiği, yapısal kırılma tarihlerinin bulgulanmasıdır. Zira, yapısal kırılma tarihlerinin göz önünde bulundurulması eş bütünleşme analizinin sapmalı sonuçlar vermesini önlemektedir. Tablo 6'da Basher ve Westerlund (2009) tarafından geliştirilmiş yapısal kırılmaları dikkate almayan ve dikkate alan eşbütünleşme analizi sonuçları sunulmaktadır. 
Tablo 6. Çoklu Yapısal Kırılmalı Eşbütünleșme Analizi

\begin{tabular}{|c|c|c|c|c|c|}
\hline Model 1 & $\begin{array}{l}\text { LM Test } \\
\text { İstatistiği }\end{array}$ & $\begin{array}{l}\text { Asimtotik } \\
\text { Olasılık } \\
\text { Değeri }\end{array}$ & Karar & $\begin{array}{c}\text { Bootstrap } \\
\text { Olasılık } \\
\text { Değerleri }\end{array}$ & Karar \\
\hline \multicolumn{6}{|c|}{ Kırılmalar Dikkate Alınmazsa } \\
\hline Sabitte & 31.367 & 0.000 & $\begin{array}{l}\text { Eşbütünleşme } \\
\text { yoktur. }\end{array}$ & 0.000 & $\begin{array}{c}\text { Eşbütünleşme } \\
\text { yoktur. }\end{array}$ \\
\hline Sabitte ve Trendde & 6.973 & 0.000 & $\begin{array}{c}\text { Eşbütünleşme } \\
\text { yoktur. }\end{array}$ & 0.000 & $\begin{array}{c}\text { Eşbütünleşme } \\
\text { yoktur. }\end{array}$ \\
\hline \multicolumn{6}{|c|}{ Kırılmalar Dikkate Alınırsa } \\
\hline Sabitte & 3.970 & 0.000 & $\begin{array}{l}\text { Eşbütünleşme } \\
\text { yoktur. }\end{array}$ & 0.889 & $\begin{array}{c}\text { Eşbütünleşme } \\
\text { vardır. }\end{array}$ \\
\hline Sabitte ve Trendde & 24.257 & 0.000 & $\begin{array}{c}\text { Eşbütünleşme } \\
\text { yoktur. }\end{array}$ & 0.697 & $\begin{array}{c}\text { Eşbütünleşme } \\
\text { vardır. }\end{array}$ \\
\hline Model 2 & $\begin{array}{l}\text { LM Test } \\
\text { İstatistiği }\end{array}$ & $\begin{array}{c}\text { Asimtotik } \\
\text { Olasılık } \\
\text { Değeri }\end{array}$ & Karar & $\begin{array}{c}\text { Bootstrap } \\
\text { Olasılık } \\
\text { Değerleri }\end{array}$ & Karar \\
\hline \multicolumn{6}{|c|}{ Kırılmalar Dikkate Alınmazsa } \\
\hline Sabitte & 30.377 & 0.000 & $\begin{array}{l}\text { Eşbütünleşme } \\
\text { yoktur. }\end{array}$ & 0.000 & $\begin{array}{l}\text { Eşbütünleşme } \\
\text { yoktur. }\end{array}$ \\
\hline Sabitte ve Trendde & 6.241 & 0.000 & $\begin{array}{c}\text { Eşbütünleşme } \\
\text { yoktur. }\end{array}$ & 0.001 & $\begin{array}{c}\text { Eşbütünleşme } \\
\text { yoktur. }\end{array}$ \\
\hline \multicolumn{6}{|c|}{ Kırılmalar Dikkate Alınırsa } \\
\hline Sabitte & 9.092 & 0.000 & $\begin{array}{l}\text { Eşbütünleşme } \\
\text { yoktur. }\end{array}$ & 0.548 & $\begin{array}{c}\text { Eşbütünleşme } \\
\text { vardır. }\end{array}$ \\
\hline Sabitte ve Trendde & 24.905 & 0.000 & $\begin{array}{l}\text { Eşbütünleşme } \\
\text { yoktur. }\end{array}$ & 0.741 & $\begin{array}{c}\text { Eşbütünleşme } \\
\text { vardır. }\end{array}$ \\
\hline
\end{tabular}

Not: Yapısal kırılma tarihleri Bootstrap ile 1000 döngü ile tespit edilmiştir.

Tablo 6'daki sonuçlara göre, kullanılan test yönteminin serilerin eşbütünleşik durumunu önemli bir düzeyde etkilemiş olduğu görülmektedir. Bu çerçevede Model 1 ve Model 2 için yapısal kırılmaları dikkate almayan analizlerde eşbütünleşme ilişkisi mevcut değilken, yapısal kırılmaları dikkate alan analizlerde 1000 döngü ile hesaplanan Bootstrap Olasılık Değerlerine (prob=0.00 değerinden büyüktür) göre eşbütünleşme ilişkisinin varlığı kabul edilmektedir. Tablo 7'de eşbütünleşme denkleminde gözlenen yapısal kırılma sayıları ve tarihleri sunulmuştur. 
Tablo 7. Eşbütünleşme Denkleminde Gözlenen Yapısal Kırılma Sayıları ve Tarihleri

\begin{tabular}{|c|c|c|c|c|c|}
\hline Ülkeler & \multirow{8}{*}{$\begin{array}{l}\frac{-1}{0} \\
\frac{0}{0} \\
\frac{0}{2}\end{array}$} & Kırılma Sayısı & $\begin{array}{c}\text { 1.Kırılma } \\
\text { Tarihi }\end{array}$ & $\begin{array}{l}\text { 2. Kırılma } \\
\text { Tarihi }\end{array}$ & $\begin{array}{l}\text { 3. Kırılma } \\
\text { Tarihi }\end{array}$ \\
\hline Kanada & & 1 & 1994 & - & - \\
\hline Fransa & & 2 & 1986 & 1998 & - \\
\hline Almanya & & 3 & 1985 & 1995 & 2005 \\
\hline İtalya & & 1 & 1992 & - & - \\
\hline Japonya & & 3 & 1979 & 1987 & 1999 \\
\hline ABD & & 1 & 1978 & - & - \\
\hline İngiltere & & 2 & 1985 & 1995 & - \\
\hline Ülkeler & \multirow{8}{*}{$\begin{array}{l}\frac{N}{2} \\
\frac{d}{0} \\
\sum\end{array}$} & Kırılma Sayısı & $\begin{array}{l}\text { 1. Kırılma } \\
\text { Tarihi }\end{array}$ & $\begin{array}{l}\text { 2. Kırılma } \\
\text { Tarihi }\end{array}$ & $\begin{array}{l}\text { 3. Kırılma } \\
\text { Tarihi }\end{array}$ \\
\hline Kanada & & 1 & 1994 & - & - \\
\hline Fransa & & 2 & 1992 & 2005 & - \\
\hline Almanya & & 3 & 1983 & 1994 & 2004 \\
\hline İtalya & & 2 & 1986 & 1994 & - \\
\hline Japonya & & 3 & 1985 & 1997 & 2005 \\
\hline ABD & & 1 & 1983 & - & - \\
\hline İngiltere & & 3 & 1979 & 1994 & 2004 \\
\hline
\end{tabular}

Not: Maksimum kırılma sayısı " 3 ” olarak ve sabitte kırılmaya izin veren test modeli seçilmiştir.

Tablo 7'de, eşbütünleşme denkleminde gözlenen yapısal kırılma sayıları ve tarihleri sunulmaktadır. Buna göre, ülke birimleri açısından farklı yapısal kırılma tarihleri ortaya çıkmasına rağmen son 40 yıllık dünya ekonomisindeki gelişmelere ülkelerin benzer refleksler göstermiş olduğu tespit edilmektedir. Bu açıdan yapısal kırılma tarihleri başarılı bir şekilde saptanmış olduğu ileri sürülebilir. Burada, 1974-75 yılında meydana gelen kapitalizmin yapısal krizinin ardından, Keynesyen uzlaşının yerini neoliberal politikaların aldığı; yani, Keynesyen politikaların rafa kaldırılarak Washington Konsensüs çerçevesinde şekillenen yeni ekonomi politikaların egemen olduğu bir dönem olarak karşımıza çıkmaktadır. Sermayenin bu yeni politikası, ekonomik gelişmenin ve kaynakların daha etkin tahsisinde piyasa mekanizmasının öncül rolüne vurgu yapmaktadır. Daha açık bir ifadeyle, kamusal alanların sermayenin özel alanlarına indirgenmesine; devletin ekonomik alanın dışında tutulmasının gerekliliğine işaret edilmektedir. Söz konusu sürecin dünya ekonomisine nüfuz etmesinde Bretton Woods Örgütleri olarak adlandırılan IMF (The International Monetary Fund), Dünya Bankası ve ilk etapta GATT (The General Agreemt on Tariffs and Trade) olarak bilinen ve daha sonraki takipçisinin Dünya Ticaret Örgütü (DTÖ) olduğu kurumların önemli bir payı vardır. Bununla birlikte, Washington Konsensüsü çerçevesinde ortaya konulan ekonomi politikalarının başlangıç aşamasında uygulanma güçlüğüyle karşılaştırıldığ düşünüldüğünden, bu yaklaşım 
1990’lı yıllarda yeniden yapılanmıştır. Öte yandan, özellikle neoliberal politikalarla birlikte özellikle kapitalizmin çevre ya da az gelişmiş ülkelerinde bir dizi bankacılık, finans, döviz kuru ve borç krizi temelli ekonomik kriz ortaya çıkmıştır. 1994 Meksika (borç krizi) ve Türkiye krizi (kur krizi), 1997 Güneydoğu Asya borç krizi, 1998 Rusya krizi, Amerika'daki dot-com balonu, 1998-2002 Arjantin krizi, 2000-2001 Türkiye bankacılık krizi bunlardan sadece bazılarıdır. Bu kriz silsilesinin etkisinin hem lokal hem de küresel düzeyde olduğu gözlenmektedir.

\subsection{Uzun Dönem Eşbütünleşme Katsayılarının Test Edilmesi}

Pesaran (2006) tarafından geliştirilmiş, YKB’nin varlığg altında geçerliliği bulunan ve güvenilir sonuçlar üreten uzun dönem eş bütünleşme katsayılarının tahminlenmesi aşamasında faydalanılan testlerden biri olan CCE (Ortak İlişkili Etkiler) yöntemi tercih edilmiştir. Ayrıca bu yöntemde, $\mathrm{T}>\mathrm{N}$ koşulunda kullanılabilen CCEMG (Ortak İlişkili Etkiler Ortalama Grup) ve $\mathrm{T}<\mathrm{N}$ koşulunda kullanılabilen CCEP (Havuzlanmış Ortak İlişkili Etkiler) olarak belirlenmiş iki tahminci geliştirilmiştir. En küçük karaler yöntemine dayanan ve karışık serilerde kullanılabilen CCE tahmincilerinde, çok faktörlü hata modeli test edilmektedir. $\mathrm{Bu}$ model aşağıda sunulmuştur (Pesaran, 2006: 971).

$$
\begin{aligned}
& y_{i t}=\alpha_{i} d_{t}+\dot{\beta}_{l} x_{i t}+e_{i t} ; \quad \quad(i=1 \ldots N, t=1 \ldots . ., m=1 \ldots k) \\
& e_{i t}=\gamma_{i} f_{t}+\varepsilon_{i t}
\end{aligned}
$$

Bu denklemlerde, $d_{t} ; \mathrm{n}$ x 1 gözlenen ortak etkileri (sabit veya mevsimsel yapay değişkenleri kapsayan), $x_{i t}$; bağımsız değişkenin yatay kesit ortalamalarını, $y_{i t}$ yatay kesit bağımlığını, $f_{t}$ gözlenemeyen ortak etkileri, $\varepsilon_{i t} ; d_{t}$ ve $x_{i t}$ 'den bağımsızlık olarak dağıtılmış olan hata terimi olarak ifade edilmektedir. Tablo 8 'de, paneli oluşturan yatay kesit birimleri (ülkeler) için CCE, panelin geneli için ise CCEMG tahmincileri kullanılmış ve Tablo 8'de sunulmuştur. 
Tablo 8. Uzun Dönem Eşbütünleşme Katsayılarının Tahmin Sonuçları

\begin{tabular}{|l|c|c|c|c|}
\hline \multicolumn{1}{|c|}{ Ülkeler } & SYğişkenler & t-ist. & EV & t-ist. \\
\hline Kanada & & & & \\
\hline Fransa & 0.003 & 1.50 & -0.005 & 1.00 \\
\hline Almanya & 0.004 & 1.33 & -0.004 & 0.80 \\
\hline İtalya & 0.001 & 1.00 & 0.003 & 0.75 \\
\hline Japonya & -0.005 & $2.50^{* *}$ & -0.005 & $2.50^{* *}$ \\
\hline ABD & 0.023 & $2.87^{*}$ & -0.012 & $3.00^{*}$ \\
\hline İngiltere & -0.001 & 1.00 & -0.001 & 0.25 \\
\hline Panel (CCEMG) & 0.001 & 1.00 & -0.004 & $4.00^{*}$ \\
\hline
\end{tabular}

Not: * ve ** işaretleri sırasıyla \%1 ve \%5 anlamlılık düzeylerini ifade etmektedir. Ayrıca t-ist. Değerleri, NeweyWest standart hatası kullanılarak hesaplanmıştır.

Tablo 8'de uzun dönem eşbütünleşme katsayıları sonuçları sunulmaktadır. Buna göre, model 1 için panelin genelinde yorumlanabilecek sonuçlar şu şekildedir: sendikalaşma yoğunluğu (SY) ile emek gelirleri arasında pozitif yönlü ya da doğrusal bir ilişki söz konusudur. Yani, sendikalaşma yoğunluğunun düşmesi durumunda emek gelirleri de düşmektedir ya da tam tersi geçerlidir. Ancak elde edilen bu sonuç, istatiksel olarak anlamlı değildir ve yorumlanamamaktadır. Homojenite testi sonucuna göre, Model 2 için ülke birimleri bazında yapılacak yorum ve değerlendirmeler daha gerçekçi ve güvenilirdir. Bu bağlamda elde edilen sonuçlara göre; İtalya, Japonya ve İngiltere'nin emek verimliliğindeki artış emek gelirlerini negatif yönde etkilemektedir. Yani, işçi sınıfı ulusal sınırlar içerisinde üretilen toplam toplumsal değerden yeterli düzeyde pay alamamakla birlikte sermaye sahiplerinin göreli paylarında artışlar meydana gelmektedir. $\mathrm{Bu}$ durum, gerek dünya gerekse de ülke ekonomilerinin gündemini fazlaca meşgul eden, sınıfsal çelişkileri derinleştiren, toplumsal ayaklanmaların önünü açan ve siyasi iktidarları tehdit eden yönü olan gelir eşitsizliğinin (adaletsizliğinin) daha ileri bir düzeye taşınmasına neden olmaktadır. Panelin geneli için de benzer sonuca ulaşılmıştır. Ancak, elde edilen sonuç istatistiksel olarak anlamlı olmadığından, yorumlanamamaktadır.

\section{SONUÇ VE DEĞERLENDİRME}

Bu çalışmada; verimlilik ile sendikalaşma oranının emek gelirleri üzerindeki etkileri, kapitalizmin merkez ülkeleri olarak kabul edilen G-7 ülkeleri için 1970-2012 dönemi verileri kullanılarak, yatay kesit bağımlılığını ve çoklu yapısal kırılmaları göz önünde bulunduran panel 
veri analizi yöntemiyle incelenmiştir. Analiz sonucunda ülkeler arasında yatay kesit bağımlığının varlığı bulgulanmaktadır. Panel birim kök testi sonucunda ise, panelin geneli için serilerin düzeyde durağan olmadıkları, ancak birinci farkları alındığında durağanlaştı̆ğ tespit edilmektedir. Bu bulgu, panel eşbütünleşme analizine geçilmesinin olanaklı olduğuna işaret etmektedir. Yapılan eşbütünleşme testi sonucunda; Model 1 ve Model 2 için yapısal kırılmaları dikkate almayan analizlerde eşbütünleşme ilişkisi bulunmazken, yapısal kırılmaları dikkate alan analizlerde eşbütünleşme ilişkisinin varlığı kabul edilmektedir.

Eşbütünleşme katsayıları sonuçlarına göre; Model 1 için panelin genelinde sendikalaşma yoğunluğu (SY) ile emek gelirleri arasında pozitif yönlü bir ilişki söz konusudur. Yani sendikalaşma yoğunluğunun düşmesi durumunda emek gelirleri de düşmekte ya da tam tersi geçerlidir. Ancak elde edilen sonuç, istatiksel olarak anlamlı değildir ve yorumlanamamaktadır. Homojenite testi sonucuna göre, Model 2 için ülke birimleri bazında yapılacak yorum ve değerlendirmelerin daha gerçekçi ve güvenilir olduğu tespit edilmiştir. $\mathrm{Bu}$ bağlamda elde edilen sonuçlara göre; İtalya, Japonya ve İngiltere'nin emek verimliliğindeki artış emek gelirlerini negatif yönde etkilemektedir. Yani, işçi sınıfı ulusal sınırlar içerisinde üretilen toplam toplumsal değerden yeterli düzeyde pay alamamakla birlikte sermaye sahiplerinin göreli paylarında artışlar meydana gelmektedir. Bu durum, gerek dünya gerekse de ülke ekonomilerinin gündemini fazlaca meşgul eden, sınıfsal çelişkileri derinleştiren, toplumsal ayaklanmaların önünü açan ve siyasi iktidarları tehdit edici yönü olan gelir eşitsizliğinin (adaletsizliğinin) daha ileri bir düzeye taşınmasına neden olmaktadır. Kısacası, sermayedarların işçi sınıfının gelirine oranla üretilen toplumsal değerden daha fazla pay almaları gelir eşitsizliği (adaletsizliği) sorunsalını dünya ekonomisinin gündemine en canlı şekilde koymaktadır. Bu sorunsal ekonomik alanın yanında; toplumsal, siyasal ve ideolojik alanları da etkisi altına almaktadır. Panelin geneli için de benzer bir sonuca ulaşılmasına rağmen elde edilen sonucun istatistiksel olarak anlamlı olmaması, söz konusu sonucun yorumlanmasına engel olmaktadır.

Nitekim, sermayenin çıkarları doğrultusunda karlılık krizini telafi etmek amacıyla uygulanmaya konulan neoliberal politikalar için 1980 dönemi, yapısal kırılmaların ortaya çıktığı dönem olarak tespit edilmekte ve bu sürece uygun olarak Washington Konsensüsü amentüsü temelinde şekillenen bir dünya ekonomisi manzarası resmedilmektedir. Yapısal kırılmalar arasında aynı zamanda merkez kapitalist ülkelerin sermaye serbestîsi ve 
finansallaşma yoluyla çevre ülkelerden kar transferi yaptığı; öte yandan, bu kanallar yoluyla dünya ekonomisine krizlerini de ihraç ettiği; çevre ülkelerde meydana gelen bankacılık, döviz kuru ve finansal kriz deneyimleri üzerinden gözlenmektedir. Ayrıca, bu krizlerin merkez ülkelere farklı zaman dilimlerinde geri döndüğü de tanıtlanmıştır. Son tahlilde, çalışmada sermayenin krizden çıkış stratejisinin başka bir sac ayağı olarak işçi sınıfının çalışma ve yaşam koşullarını neden dönüştürmek istendiği ve bu temelden hareketle daha önceki dönemlerde elde edilen kazanımların niçin aşındırıldığının ampirik kanıtları ortaya konulmaktadır.

\section{Kaynakça}

Alvaredo, F, A B Atkinson, T Piketty, E Saez, and G Zucman (2015), The World Wealth and Income Database, http://www.wid.world/.

Asaleye, Abiola and Olurinola, Isaiah \& Oloni, E.F. \& Olufemi, Ogunjobi. (2017), "Productivity Growth, Wages and Employment Nexus: Evidence from Nigeria'Journal of Applied Economic Sciences. 12. 1362-1376.

Barrades R., (2019), "Financialization and Neoliberalism and The Fall in The Labor Share: A Panel Data Econometric Analysis for The European Union Countries" Review of Radical Political Economics, 51(3): 383-417.

Barth, E., Bryson A. and Dale-Olsen H. (2017), Union Density, Productivity and Wages, IZA Discussion Paper, No. 11111.

Basher, S.A. ve Westerlund, J. (2009), "Panel Cointegration and the Monetary Exchange Rate Model', Economic Modelling, 26, 506-513.

Bentolila, S., and G. Saint-Paul. (2003), "Explaining Movements in Labor's Share", Contributions to Macroeconomics, 3:1-31.

Brenner, R (1998), "The Economics of Global Turbu-lence: A Special Report on the World Economy, 1950-98”, Special Issue, New Left Review, No 229, May/June, pp 262.

Breuer, Boucher, Robert McNown ve Myles Wallace (2001), “Misleading Inference form Panel Unit Root Tests with an Illustration from Purchasing Power Parity", Review of International Economics, 9(3), pp. 482-493.

Clarke, S. (2007) Marx’ın Kriz Teorisi, (çev. Cumhur Atay), Otonom Yayınları: İstanbul.

Carter, S. (2007), “Real Wage Productivity Elasticity Across Advanced Economies 19631996", Journal of Post-Keynesian Economics, 29: 573- 600. 
Fichtenbaum R. (2011), “Do Unions Affect Labor's Share of Income: Evidence Using Panel”' American Journal of Economics and Sociology,70(3): 784-810.

Fine, B., \& Saad-Filho, A. (2017), Thirteen Things You Need to Know About Neoliberalism, Critical Sociology, 43(4-5), 685-706.

Gehrke, L., Kühn, A. T., Rule, D., Moore, P., Bellmann, C., Siemes, S., Dawood, D., Lakshmi, S., Kulik, J. and Standley, M. (2015), "A Discussion of Qualifications and Skills in the Factory of the Future: A German and American Perspective', VDI / ASME Industry 4.0 White Paper, pp. 1-28.

Harvey, D (2005), A Brief History of Neoliberalism (New York: Oxford University Press).

Harvey D. (2008), Yeni Emperyalizm (Çev. Hür Güldü), Everest Yayınları. İstanbul.

Harvey D. (2015), On Yedi Çelişki ve Kapitalizmin Sonu (Çev. Esin Soğancılar). Sel Yayıncılık. İstanbul.

Macpherson D. A. (1990), “'Trade Unions and Labor's Share in U.S. Manufacturing Industries, International Journal of Industrial Organization, Volume 8, Issue 1, Pages 143-151

Marx. K. [1894] (2011). Kapital 3(Çev. Alaatin Bilgi). Sol yayınları. Ankara.

Pesaran, M. H., Ullah A. and Yamagata T. (2008), “A Bias- Adjusted LM Test of Error CrossSection Independence”, The Econometrics Journal, 11(1), pp. 105-127.

Pesaran, M. H. (2007), “A Simple Panel Unit Root Test in The Presence of Cross- Section Dependence", Journal of Applied Econometrics, 22(2), pp. 265-312.

Polat F ve Basmacı M. (2018), "Neoliberalizm Heyulas1: Keynesyenizme Saldırı Mi? Sermayenin Zorunlu İstikameti Mi?', Ekonomi İsletme Siyaset ve Uluslararası İlişkiler Dergisi, 3 (2) , 79-128 .

Satlıgan N. ve Savran S. (2009), Dünya Kapitalizminin Krizi, Derleme Kitap, Belge Yayınları, İstanbul.

Shaikh, A. (1987). The Falling Rate of Profit and the Economic Crisis in the US. in Robert Cherry et al (ed.), The Imperilled Economy, Book I, Union for Radical Political Economy.

Shaikh A. ve Tonak A. E. (2012), Milletlerin Zenginliğinin Ölçülmesi, Ulusal Hesapların Ekonomi Politiği (Çev. Hakan Arslan), Yordam Kitap, İstanbul.

Sharpe, A, Arsenault J. F. and Harrison P. (2008), "The Relationship Between Labour Productivity and Real Wage Growth in Canada and OECD Countries", Centre for the Study of Living Standards, Research Report, No 2008-8. 
Savran, S. (2013), Üçüncü Büyük Depresyon: Kapitalizmin Alacakaranlığı, Yordam Kitap: İstanbul.

Thompson E.P. [1966] (2015), İngiliz İşçi Sınıfının Oluşumu (Ayşe Buğra Önsöz). Birikim Yayınları.

Tsoku, J. and Matarise, F. (2014), “An Analysis of the Relationship Between Remuneration (Real Wage) and Labour Productivity in South Africa', Journal of Educational and Social Research, 10.5901/jesr.2014.v4n6p59.

Vakulabharanam, Vamsi. (2009) "The Recent Crisis in Global Capitalism: Towards a Marxian Understanding', Economic and Political Weekly. 44. 144-145. 10.2307/40278673.

Wallace M., Leicht K. T., Raffalovich E L. (1999), “Unions, Strikes, and Labor's Share of Income: A Quarterly Analysis of the United States, 1949-1992', Social Science Research, Volume 28, Issue 3, Pages 265-288 